\title{
不均等曲げせん断力を受ける周辺固定支持平板の弾性座屈耐力の導出 AN ANALYTICAL METHOD FOR ELASTIC BUCKLING STRENGTH OF CLUMPED PLATE UNDER UNEQUAL BENDING AND SHEAR
}

\author{
五十嵐 規矩夫*，鈴木 琢也** \\ Kikuo IKARASHI and Takuya SUZUKI
}

\begin{abstract}
In the past, various researches are performed about buckling of plate. But, about clumped plate under combine stress, few researches are performed. Because it is diffecult to consider both clumped condition and combine stress. However, the buckling shape of beam is alike the one of clumped plate. So, it is important to understand buckling of clumped plate under unequal bending and shear owing to understanding the buckling behavior.

The purpose of this study is to show the method for elastic buckling strength of clumped plate under unequal bending and shear. For this problem, new function of deflection is proposed. And, energy method with it is proposed as method for this buckling problem. It is showed that it is easy to understand buckling strength and shape of clumped plate under combined stress with this method.
\end{abstract}

Keywords : Elastic buckling, Shear, Unequal bending, Clumped plate, Energy method 弾性座屈，せ九断，不均等曲げ，周辺固定支持平板，エネルギー法

$\S 1$. 序

H形鋼梁の耐力, 塑性変形能力や崩壊性状についてはこれまでに多 くの研究がなされてきており,その性状について多くの有益な知見が

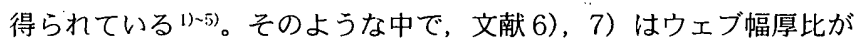
大きくせん断力の影響を強く受ける梁の性状について取り扱い，その 性状を明らかにするとともに,このような梁の最大耐力がウェブの座 屈によって決定されていることを示している。また, そのウエブの座 屈にはせん断のみではなく曲げ応力の影響も大きいことを明らかにし ている。このことから, 梁の塑性変形能力や崩壊性状をより正確に把 握するためには, せん断と曲げの複合応力を考慮した板の座屈性状を より詳細に把握する必要があると言える。

しかし, 梁に作用するせん断応力と曲げ応力を再現した平板の座屈 についての研究は少なく, 弹性座屈性状すら十分に把握されていると は言い難い。これに対し，文献 8) では不均等曲げせん断力を受ける 四辺単純支持平板の弾性座屈について調べ, 簡便な耐力算定式を提案 している。しかしながら,せん断力の影響の大きな梁は写真 1 に示す ようにフランジが揬れずにウェブの座屈のみで崩壊するものも存在す る6)。この場合座屈波形は周辺固定支持のものに近くなると考えられ る。現在一般的には，周辺支持条件を単純支持としてのみウェブ板の 座屈を取り扱っているものが多い。しかしこの扱いは, ウェブ板の座 屈耐力を過小評価する可能性もあり，十分であるとは考えられない。
このような梁の弾性座屈性状を求めるにはせん断および曲げの複合 応力が作用する四辺固定支持平板の弾性座屈耐力評価も必要になると 考えられるが，これまでに四辺固定支持平板の座屈解析は純せん断， 純曲げもしくは純圧縮といった単純な応力状態のものしか行われてい ない早10)。せん断と曲げの複合応力を受ける四辺固定支持平板の座屈 解析はその座屈波形が予測できるようなもの以外はほとんど行われて いないというのが現状である。これは四辺固定の境界条件を導入する こと自体が困難であり,さらに複合応力を導入した場合, 計算がより 複雑なものになってしまうためであると考えられる。

しかし, せん断と曲げの複合応力を受ける四辺固定支持平板の座屈 酎力を求めることができるならば,梁の崩壊性状をより詳細に理解で

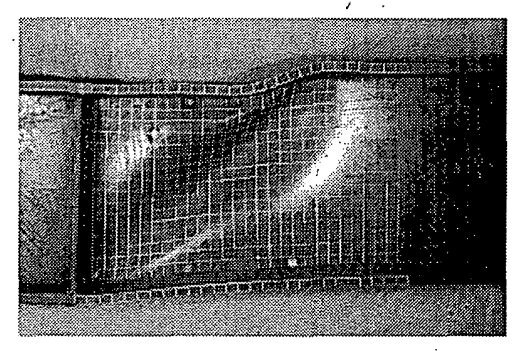

写真 1 . 梁ウェブの座屈変形 (文献 6 )
* 東京工業大学大学院理工学研究科建築学専攻 助教授・博士 (工学)

** 東京工業大学大学院理工学研究科建築学専攻 博士後期課程・修士 (工学)
Assoc. Prof., Dept. of Architecture and Building Faculty of Engineering, Graduate School of Science and Engineering, Tokyo Institute of Technology, Dr. Eng. Graduate Student, Dept. of Architecture and Building Faculty of Engineering, Graduate School of Science and Engineering, Tokyo Institute of Technology, M. Eng. 
きる可能性がある。また, 梁ウェブ周辺の境界条件が座屈耐力に与え る影響を知るためにも，その上限値を知ることは重要である。

そこで本研究においては,独自の変位関数を提案しエネルギー法を 用いることによって図 1 に示すような不均等曲げせん断力を受ける四 辺固定支持平板の座屈耐力および座屈波形を算出する手法について論 じることを目的とする。

\section{§2. 本研究で提案する変位関数とその特性}

エネルギー法による四辺固定支持平板の座屈解析が困難になる理由 は，境界条件を満たす変位関数の設定が難しいためである。一般的に エネルギー法においては変位関数をそれぞれが境界条件を満たし直交 関係にある無限級数の形でおく。しかしながら，固定支持の場合それ らの条件を満たす無限級数を用いて座届解析手法を示した研究は, 著 者が知る限り見当たらない。このため，固定支持においては，波形を ある程度予測でき,多くの級数をとらずに済む比較的単純な外力条件 のもののみが解かれ，波形を予測することが難しい複合応力の場合が 解かれてこなかったと考えられる。

しかし，図1に示すような複合応力を受ける四辺固定支持平板の座 屈荷重を求める場合, 座屈波形を限定することは難しいため変位関数 を無限級数の形で与えることが必要となる。そこで本研究では変位関 数を以下の式のような形でおくことを提案する。なお，座標軸につい ては図 1 に示すものとする。

$$
\begin{array}{r}
w=\sum_{i}^{\infty} \sum_{j}^{x} a_{i j} u_{i} v_{j} \\
u_{i}=\sin \frac{\pi x}{a} \sin \frac{i \pi x}{a} \\
v_{j}=\sin \frac{\pi y}{b} \sin \frac{j \pi y}{b}
\end{array}
$$

ここで $u_{i}$ は $x$ のみ関数であり $v_{j}$ は $y$ のみ関数である。 $u_{i}$ および

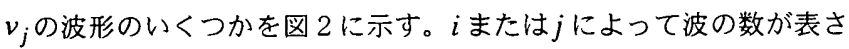
れ，各境界において $u_{i} お よ ひ ゙ v_{j}$ は以下の条件を満たす。

$$
\begin{aligned}
& x=0, a \text { において, } u_{i}=0 \quad \frac{d u_{i}}{d x}=0 \quad \ldots \ldots \ldots \ldots \\
& y=0, b \text { において, } \quad v_{j}=0 \quad \frac{d v_{j}}{d y}=0 \ldots \ldots \ldots \ldots
\end{aligned}
$$

したがって,この級数によって表された変位関数は四辺固定支持平 板の境界条件である以下の式を満たす。

$$
\begin{aligned}
& x=0, a \text { において, } w=0 \quad \frac{\partial w}{\partial x}=0 \quad \ldots \ldots \ldots \ldots \text { (6) } \\
& y=0, b \text { において, } w=0 \quad \frac{\partial w}{\partial y}=0 \quad \ldots \ldots \ldots \text { (7) }
\end{aligned}
$$

しかしながら、これらの級数には直交関係が存在しない。このた め,これらの級数は，以下の式によって表される直交関数がもつ特性 を持たない級数となる。

$$
\begin{array}{ll}
i \neq m \text { において, } & \int_{0}^{a} u_{i} \cdot u_{m} d x=0 \\
j \neq n \text { において, } & \int_{0}^{b} v_{j} \cdot v_{n} d y=0
\end{array}
$$

変位関数としておいたそれぞれの級数に直交関係が存在しない場 合,(8),(9)式のような関係を用いることができないため座屈荷重を求め る際に必要となるポテンシャルエネルギーの算出式が複雑になる。ま

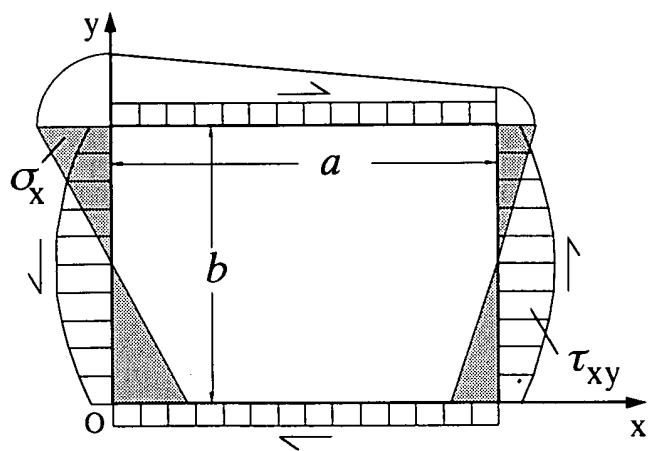

図 1 ウェブに作用する応力分布

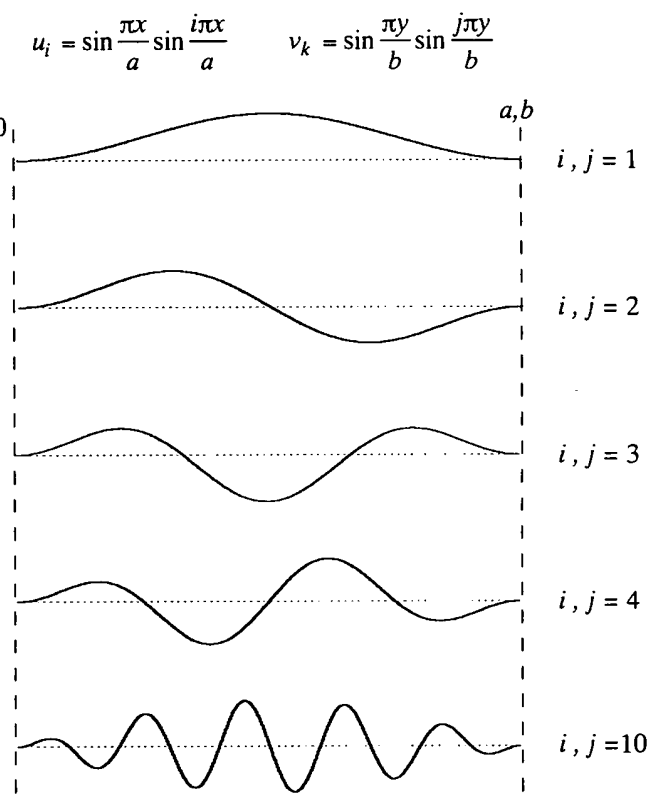

図 2 本研究で提案する変位関数の波形

た, 直交性がないために多くの級数をとっても真の座屈波形を表現 できず，精確な座屈荷重が算出されない可能性もある。

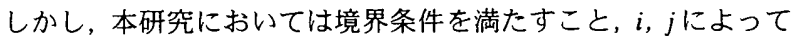
波形の形が容易に理解できることに着目し，この変位関数を用い て, エネルギー法によって複合応力を受ける四辺固定支持平板の座 屈耐力を求めることとした。

\section{§3. エネルギー法による一般式の展開}

前章において変位関数が定義された。本章においてはエネルギー法 による一般的な解法原理について述べ, 板要素に複合応力が作用し座 届を生じる場合の一般関倸式を導出する。

\section{1 座屈応力度}

板に作用する直応力度およびせん断応力度分布は以下のようにお く。なお座標軸は図 1 によるものとし，直応力については引張側を 正，せん断応力については図 1 に示す向きを正とする。ここで, $\sigma_{\mathrm{x} 1}, \tau_{\mathrm{xy}}$ はそれぞれの最大応力度である。

$$
\sigma_{\mathrm{x}}=\sigma_{\mathrm{x} 1} f(x, y) \quad \tau_{\mathrm{xy}}=\tau_{\mathrm{xy}} g(x, y)
$$


続いて, $\tau_{\mathrm{xy} 1}$ を $\sigma_{\mathrm{x} 1}$ を基準として以下のように表す。

$\tau_{x y 1}=\alpha \sigma_{\mathrm{x} 1}$

したがって,(11)式を(10)式に代入することで, 応力度分布は以下の ように表すことができる。

$\sigma_{x}=\sigma_{x 1} f(x, y) \quad \tau_{x y}=\alpha \sigma_{x 1} g(x, y) ， \ldots \ldots \ldots(12)$

そして, 座屈時の $\sigma_{\mathrm{x} 1}$ を基淮となる応力度 $\sigma_{\mathrm{e}}$ の倍数で表し，この倍 数 $k$ を座屈係数とする。すなわち,

$$
\begin{array}{r}
\left(\sigma_{\mathrm{x} 1}\right)_{c r}=k \sigma_{\mathrm{c}} \quad \ldots . \\
\text { ここで, } \quad \sigma_{\mathrm{c}}=\frac{\pi^{2} D}{t b^{2}} \\
\quad D=\frac{E t^{3}}{12\left(1-v^{2}\right)}
\end{array}
$$

ここで $t$ は板厚， $E$ はヤング率， $v$ はポアソン比をそれぞれ表して いる。これより, 座屈時の応力度分布は以下の式によって表されるも のとなる。

$$
\left(\sigma_{\mathrm{x}}\right)_{c r}=k \sigma_{c} f(x, y) \quad\left(\tau_{\mathrm{xy}}\right)_{c r}=k \alpha \sigma_{\mathrm{c}} g(x, y) \quad \ldots \ldots \ldots(16)
$$

したがって，想定する板に作用する応力度分布から $f(x, y), g(x, y), \alpha$ を定め㧈ば，応力度分布は座標 $x$ および $\mathrm{y}$ と座屈係数 $k$ によって表さ れる関数となる。

\section{2 解法原理}

エネルギー理論によれで, 座屈条件は座屈曲面仮想変位Wに伴う二 次のエネルギー変化が零になることから以下の式で表される9。

$$
\begin{aligned}
\frac{1}{2} D \int_{0}^{a} \int_{0}^{b} & {\left[\left(\frac{\partial^{2} w}{\partial x^{2}}+\frac{\partial^{2} w}{\partial y^{2}}\right)^{2}-2(1-v)\left\{\frac{\partial^{2} w}{\partial x^{2}} \cdot \frac{\partial^{2} w}{\partial y^{2}}-\left(\frac{\partial^{2} w}{\partial x \partial y}\right)^{2}\right\}\right] d x d y } \\
& +\frac{1}{2} k \sigma_{e} t \int_{0}^{a} \int_{0}^{b}\left[f(x, y)\left(\frac{\partial w}{\partial x}\right)^{2}+2 \alpha g(x, y) \frac{\partial w}{\partial x} \cdot \frac{\partial w}{\partial y}\right] d x d y=0 \quad \ldots(17)
\end{aligned}
$$

さらにこの式は $I_{1}, I_{2}$ を用いて以下のように書き換えられる。

$I_{1}+k I_{2}=0 \ldots \ldots \ldots \ldots \ldots \ldots$ (18) ここで,

$$
\begin{aligned}
& I_{1}=\frac{1}{2} D \int_{0}^{a} \int_{0}^{b}\left[\left(\frac{\partial^{2} w}{\partial x^{2}}+\frac{\partial^{2} w}{\partial y^{2}}\right)^{2}-2(1-v)\left\{\frac{\partial^{2} w}{\partial x^{2}} \cdot \frac{\partial^{2} w}{\partial y^{2}}-\left(\frac{\partial^{2} w}{\partial x \partial \partial}\right)^{2}\right\}\right] d x d y \\
& I_{2}=\frac{1}{2} \sigma_{e} t \int_{0}^{a} \int_{0}^{b}\left[f(x, y)\left(\frac{\partial w}{\partial x}\right)^{2}+2 \alpha g(x, y) \frac{\partial v}{\partial x} \cdot \frac{\partial v}{\partial y}\right] d x d y \ldots \ldots
\end{aligned}
$$

(18)式において $k$ の值を極小とする条件から, 次の一般座屈条件式 が得られる。

$$
\frac{\partial I_{1}}{\partial a_{m n}}+k \frac{\partial I_{2}}{\partial a_{m n}}=0
$$

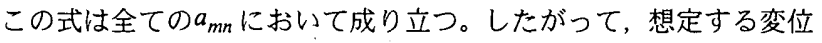
'関数の項数だけ(21)式の形で座屈条件式が得られる。

また，(1)式を(19)，(20)式に代入し，それぞれ $a_{m n}$ で微分すると，

$$
\begin{aligned}
& \frac{\partial I_{1}}{\partial a_{m n}}=D \sum_{i} \sum_{j} a_{i j} \int_{0}^{a} \int_{0}^{b}\left\{\left(\ddot{u}_{i} v_{j}+u_{i} \ddot{v}_{j}\right)\left(\ddot{u}_{m} v_{n}+u_{m} \ddot{v}_{n}\right)\right. \\
& \left.-(1-v)\left(\ddot{u}_{m} v_{n} u_{i} \ddot{v}_{j}+\ddot{u}_{i} v_{j} u_{m} \ddot{v}_{n}+2 \dot{u}_{i} \dot{v}_{j} \dot{u}_{m} \dot{v}_{n}\right)\right\} d x d y \quad \ldots .(22) \\
& \frac{\partial I_{2}}{\partial a_{m n}}=\sigma_{e} t \sum_{i} \sum_{j} a_{i j} \int_{0}^{a} \int_{0}^{b}\left\{f(x, y)\left(\ddot{u}_{i} v_{j} \dot{u}_{m} v_{n}\right)\right. \\
& \left.+\alpha g(x, y)\left\{\dot{u}_{m} v_{n} u_{i} \dot{v}_{j}+\dot{u}_{i} v_{j} u_{m} \dot{v}_{n}\right)\right\} d x d y \quad \ldots(23) \\
& \text { ここで, } \quad \dot{u}_{i}=\frac{\partial u_{i}}{\partial x} \quad \ddot{u}_{i}=\frac{\partial^{2} u_{i}}{\partial x^{2}} \quad \dot{v}_{j}=\frac{\partial v_{j}}{\partial y} \quad \ddot{v}_{j}=\frac{\partial^{2} v_{j}}{\partial y^{2}} \ldots \ldots \text { (24) }
\end{aligned}
$$

となり, $\partial I_{1} / \partial a_{m n}, \partial I_{2} / \partial a_{m n}$ ともに各 $a_{i j}$ の一次式となる。

したがって,(21)式の形で表される一次同次方程式は二つの正方行列 A,Bによって以下のように表すことができる。

$$
\mathbf{A}\left\{a_{i j}\right\}+k \mathbf{B}\left\{a_{i j}\right\}=0
$$

ここで, $A_{i j m n}, B_{i j m n}$ を，それぞれ(19)および(20)式を $a_{m n}$ で微分した時 の $a_{i j}$ の係数として定義する。これらはそれぞれ行列 $\mathbf{A}, \mathbf{B}$ を構成する各 成分となる。一例として，図 3 に $A_{i j m n}$ による行列 $\mathbf{A}$ の構成を示す。 これらは,(22),(23)式よりそれぞれ

$$
\begin{aligned}
A_{i j m n}= & D \int_{0}^{a} \int_{0}^{b}\left\{\left(\ddot{u}_{i} v_{j}+u_{i} \ddot{v}_{j}\right)\left(\ddot{u}_{m} v_{n}+u_{m} \ddot{v}_{n}\right)\right. \\
& \left.-(1-v)\left(\ddot{u}_{m} v_{n} u_{i} \ddot{v}_{j}+\ddot{u}_{i} v_{j} u_{m} \ddot{v}_{n}+2 \dot{u}_{i} \dot{v}_{j} \dot{u}_{m} \dot{v}_{n}\right)\right\} d x d y \quad \ldots(26) \\
B_{i j m n}= & \sigma_{c} t \int_{0}^{a} \int_{0}^{b}\left\{f(x, y)\left(\dot{u}_{i} v_{j} \dot{u}_{m} v_{n}\right)+\alpha g(x, y)\left(\dot{u}_{m} v_{n} u_{i} \dot{v}_{j}+\dot{u}_{i} v_{j} u_{m} \dot{v}_{n}\right)\right\} d x d y
\end{aligned}
$$$$
\cdots \cdot(27)
$$

と表せる。また, (27)式に(14)式を代入すると

$$
B_{i j m n}=\frac{\pi^{2}}{b^{2}} D \int_{0}^{a} \int_{0}^{b}\left\{f(x, y)\left(\dot{u}_{i} v_{j} \dot{u}_{m} v_{n}\right)+\operatorname{ag}(x, y)\left(\dot{u}_{m} v_{n} u_{i} \dot{v}_{j}+\dot{u}_{i} v_{j} u_{m} \dot{v}_{n}\right)\right\} d x d y
$$

となる。ここで, 行列 $\mathbf{A}^{\prime}, \mathbf{B}^{\prime}$ を

$$
\begin{aligned}
& \mathbf{A}=\frac{\mathrm{D} \pi^{2}}{b^{2}} \mathbf{A}^{\prime} \\
& \mathbf{B}=\frac{\mathrm{D} \pi^{2}}{b^{2}} \mathbf{B}^{\prime}
\end{aligned}
$$

と定め,これらの各成分をそれぞれ $A_{i j m n}^{\prime}, B_{i j m n}^{\prime}$ とすると, $A_{i j m n}^{\prime}, B_{i j m n}^{\prime}$ はそ れぞれ以下のようになる。

$$
\begin{aligned}
& A_{i j m n}^{\prime=}=\frac{b^{2}}{\pi^{2}} \int_{0}^{a} \int_{0}^{b}\left\{\left(\ddot{u}_{i} v_{j}+u_{i} \ddot{v}_{j}\right)\left(\ddot{u}_{m} v_{n}+u_{m} \ddot{v}_{n}\right)\right. \\
& \left.\quad-(1-v)\left(\ddot{u}_{m} v_{n} u_{i} \ddot{v}_{j}+\ddot{u}_{i} \dot{v}_{j} u_{m} \ddot{v}_{n}+2 \dot{u}_{i} \dot{v}_{j} \dot{u}_{m} \dot{v}_{n}\right)\right\} d x d y . \ldots(31) \\
& B_{i j m n}^{\prime}=\int_{0}^{a} \int_{0}^{b}\left\{f(x, y)\left(\dot{u}_{i} v_{j} \dot{u}_{m} v_{n}\right)+\alpha g(x, y)\left(\dot{u}_{m} v_{n} u_{i} \dot{v}_{j}+\dot{u}_{i} v_{j} u_{m} \dot{v}_{n}\right)\right\} d x d y
\end{aligned}
$$$$
\cdots \cdots(32)
$$

また,(29)，(30)式より(25)式は次のように表される。

$\left\{\mathbf{A}^{\prime}+k \mathbf{B}^{\prime}\right\}\left\{a_{i}\right\}=0 \ldots \ldots \ldots \ldots \ldots$ (33) (34)式において $\left\{a_{i j}\right\}$ が $\{0\}$ 以外の解を持つ時, $k$ は固有値, $\left\{a_{i i}\right\}$ は固有 ベクトルとして解が与えられる。よって，この(33)式の固有値のうち 最も小さなものが板の座屈係数となり, その時の固有ベクトル $\left\{a_{i j}\right\}$ か ら座屈波形が定まる。

3.3 マトリックスの決定

行列 $\mathbf{A}^{\prime}, \mathbf{B}^{\prime}$ を(31)式および(32)式によって定義すれば,(33)式の固有 値問題を解くことによって座屈係数, 座屈波形とも求まる。しかし， 本研究で提案する变位関数を用いる場合, 行列 $\mathbf{A}^{\prime}, \mathbf{B}^{\prime}$ の各要素を定義

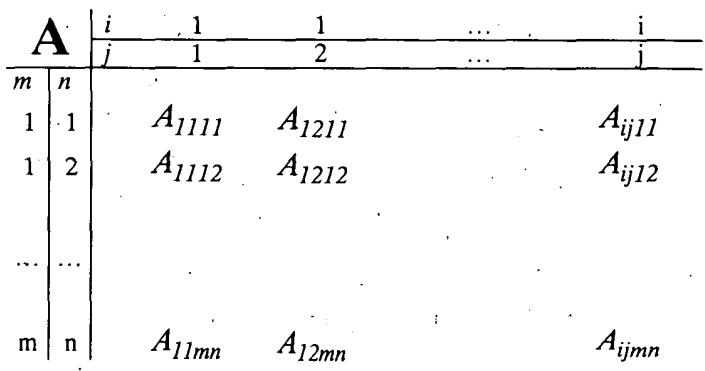

図 $3 A_{i j m n}$ による行列 $\mathbf{A}$ の構成 
するには複雑な積分問題を解く必要が生じる。これは本研究で提案す る変位関数に用いる級数が直交条件を満たしていないためである。こ のために四辺単純支持の場合に比べて行列の各要素はかなり複雑なも のになる。ここではその各要素の算出過程について述べる。

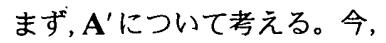

$$
\begin{array}{ll}
U_{1}(i, m)=\int_{0}^{b} u_{i} \cdot u_{m} d x & V_{1}(j, n)=\int_{0}^{b} v_{j} \cdot v_{n} d y \\
U_{2}(i, m)=\int_{0}^{a} \dot{u}_{i} \cdot \dot{u}_{m} d x & V_{2}(j, n)=\int_{0}^{b} \dot{v}_{j} \cdot \dot{v}_{n} d y \\
U_{3}(i, m)=\int_{0}^{b} \ddot{u}_{i} \cdot \ddot{u}_{m} d x & V_{3}(j, n)=\int_{0}^{b} \ddot{v}_{j} \cdot \ddot{v}_{n} d y \\
U_{4}(i, m)=\int_{0}^{a} \ddot{u}_{i} \cdot u_{m} d x & V_{4}(j, n)=\int_{0}^{b} \ddot{v}_{j} \cdot v_{n} d y
\end{array}
$$

とおくと,(31)式の第 1 項および第 2 項はそれぞれ次のようになる。

$$
\frac{b^{2}}{\pi^{2}}\left\{U_{3}(i, m) \cdot V_{1}(j, n)+U_{4}(i, m) \cdot V_{4}(n, j)\right.
$$$$
\left.U_{1}^{(i, m)} \cdot V_{3}(j, n)+U_{4}(m, i) \cdot V_{4}(j, n)\right\} \cdots(35)
$$

$\frac{b^{2}}{\pi^{2}}(1-v)\left\{U_{4}(m, i) \cdot V_{4}(j, n)+U_{4}(i, m) \cdot V_{4}(n, j)-2 \cdot U_{2}(i, m) \cdot V_{2}(n, j)\right\} \cdots(36)$.

なお，それぞれの積分結果についてはappendixを参照するものとす る。appendixより(34)式は全て対称式となるので, (35), (36)式はそれぞ れ以下のように表せる。

$$
\begin{aligned}
& \frac{b^{2}}{\pi^{2}}\left\{U_{3}(i, m) \cdot V_{1}(j, n)+U_{1}(i, m) \cdot V_{3}(j, n)+2 \cdot U_{4}(i, m) \cdot V_{4}(j, n)\right\} \quad \ldots \text { (37) } \\
& \frac{b^{2}}{\pi^{2}(1-v)}\left\{2 \cdot U_{4}(i, m) \cdot V_{4}(n, j)-2 \cdot U_{2}(i, m) \cdot V_{2}(n, j)\right\} \quad \ldots \ldots \text { (38) } \\
& \text { さらに, appendixより } \\
& U_{2}(i, m)=-U_{4}(i, m) \\
& V_{2}(j, n)=-V_{4}(j, n)
\end{aligned}
$$

であるので, 結局(38)式は零となる。したがって，

$A_{i j m n}^{\prime}=\frac{b^{2}}{\pi^{2}}\left\{U_{3}(i, m) \cdot V_{1}(j, n)+U_{1}(i, m) \cdot V_{3}(j, n)+2 \cdot U_{4}(i, m) \cdot V_{4}(j, n)\right\} \quad \cdot(40)$ なお，(34)式の対称性は変位関数を単純支持平板の一般式，

$$
u_{i}=\sin \frac{i \pi x}{a} \quad v_{j}=\sin \frac{j \pi y}{b}
$$

とした場合にも成り立つ。これより, 四辺固定支持だけではなく, 四 辺単純支持, あるいは二辺固定一二辺単純支持という境界条件におい ても(39)式の值は零となり， $A_{i j m n}^{\prime}$ は(40)式によって表される。

続いて, 行列 $\mathbf{B}^{\prime}$ について考える。行列 $\mathbf{B}^{\prime}$ は(32)式からも分かるよう に応力度分布関数の影響を受ける。したがって, 外力条件によって必 要な積分計算が異なる。このため, 行列 $\mathbf{B}^{\prime}$ については次章以降のそれ ぞれの外力条件に対して適宜, 算出式を示すこととする。なお, その 際に生じる積分計算についても appendix 参照することとする。

\section{§4. 本研究で提案する変位関数の妥当性}

2 章で述べたように, 本研究で四辺固定支持平板の変位関数として 用いた級数はそれぞれに直交関係を持たない。このため, その妥当性 についての検証が必要となる。本章では3章までに述べられた手法を 用いて四辺固定支持平板が純圧縮, 純せん断, 純曲げ応力を受ける際 の座屈係数を算出し, 既往の研究結果 ${ }^{10)}$ と比較することにより, 本研 究で提案する変位関数の妥当性について検証する。な拉純曲げについ ては四辺固定支持平板の研究成果がないため, 二辺固定支持-二辺単 純支持のものについても算出し検証を行う。なお,この解析において は(1) (3)式で表される級数を $i, j$ ともに $1 \sim 20$ までとって座屈係数を 算出している。また, 級数項の增大による解の収束性の確認も行う。 4.1 純圧縮応力下 純圧縮の場合の応力度分布は以下の式で表現される。

$$
\sigma_{\mathrm{x}}=\sigma_{\mathrm{x} 1} \quad \tau_{\mathrm{xy}}=0
$$

したがって，

$f(x, y)=1$

$\alpha g(x, y)=0 \ldots \ldots \ldots(43)$

となる。これより, 行列 $\mathbf{B}^{\prime}$ の各成分 $B_{i j m n}^{\prime}$ は(32)式より

$B_{i j m n}^{\prime}=\int_{0}^{a} \int_{0}^{b} \dot{u}_{i} v_{j} \dot{u}_{m} v_{n} d x d y \ldots \ldots \ldots \ldots \ldots \ldots \ldots \ldots$

さらに(34)式より

$B_{i j m n}^{\prime}=U_{2}(i, m) \cdot V_{1}(j, n) \quad \ldots \ldots \ldots \ldots \ldots$ (45)

となる。この(45)式と(40)式から(33)式の一般固有値問題の二つの行 列が定まり, 純圧縮の場合の座屈係数を求めることができる。

その結果を既往の研究結果 ${ }^{10)}$ とともに図 4 に示す。

4.2 純せん断応力下

純せん断の場合の応力度分布は以下の式で表現される。

$\sigma_{\mathrm{x}}=0 \quad \tau_{\mathrm{xy}}=\tau_{\mathrm{xy} 1} \ldots \ldots \ldots \ldots$ (46)

したがって,

$f(x, y)=0$

$\alpha g(x, y)=1 \ldots \ldots \ldots(47)$

となる。これより, 行列 $\mathbf{B}^{\prime}$ の各成分 $B_{i j m n}^{\prime}$ は(32)式から

$B_{i j m n}^{\prime}=\int_{0}^{a} \int_{0}^{b}\left(\dot{u}_{m} v_{n} u_{i} \dot{v}_{j}+\dot{u}_{i} v_{j} u_{m} \dot{v}_{n}\right) d x d y \quad \ldots \ldots$ (48)

ここで,

$U_{5}(i, m)=\int_{0}^{a} \dot{u}_{i} \cdot u_{m} d x \quad V_{5}(j, n)=\int_{0}^{b} \dot{v}_{j} \cdot v_{n} d y \quad \ldots \ldots \ldots$ (49)

とおくと,(48)式は

$B_{i j m n}^{\prime}=U_{5}(m, i) V_{5}(j, n)+U_{5}(i, m) V_{5}(n, j) \quad \ldots \ldots \ldots(50)$

となる。また appendix より(49)式はそれぞれ，

$U_{5}(i, m)=-U_{5}(m, i) \quad V_{5}(j, n)=-V_{5}(n, j) \quad \ldots \ldots \ldots(51)$

の関係を満たす。したがって (50)式は結局

$B_{i j m n}^{\prime}=2 U_{5}(m, i) V_{5}(j, n) \ldots \ldots \ldots \ldots \ldots(52)$ となる。この(52)式と(33),(40)式から純圧縮の場合と同様に純せん断 の場合の座屈係数を求めることができる。

その結果を既往の研究結果 ${ }^{10)}$ とともに図 5 に示す。

4.3 純曲げ応力下

純曲げの場合の応力度分布は以下の式のようになる。

$$
\begin{aligned}
& \sigma_{\mathrm{x}}=\sigma_{\mathrm{x} 1}\left(1-\frac{2}{b} y\right) \quad \tau_{\mathrm{xy}}=0 \quad \ldots \ldots \ldots \ldots \\
& \text { したがって, } \\
& f(x, y)=1-\frac{2}{b} y \quad \alpha g(x, y)=0 \ldots \ldots \ldots \ldots \\
& \text { となる。これより行列 } \mathbf{B}^{\prime} \text { の各成分 } B_{i j m n}^{\prime} \text { は(32)式より }
\end{aligned}
$$

$$
B_{i j m n}^{\prime}=\int_{0}^{a} \int_{0}^{b}\left(1-\frac{2}{b} \cdot y\right)\left(\dot{u}_{i} v_{j} \dot{u}_{m} v_{n}\right) d x d y
$$

さらに,

$U_{6}(i, m)=\int_{0}^{R} x \cdot u_{i} \cdot u_{m} d x \quad V_{6}(j, n)=\int_{0}^{b} y \cdot v_{j} \cdot v_{n} d y \quad \ldots \ldots(56)$ とおくと, 式(55)は

$$
B_{i j m n}^{\prime}=U_{2}(i, m) \cdot\left(V_{1}(j, n)-\frac{2}{b} V_{6}(j, n)\right)
$$

となる。この(57)式と(33),(40)式から純圧縮の場合と同様に純曲げの 場合の座屈係数を求めることができる。なお, 純曲げについては既往 の研究成果がないため $\mathrm{x}$ 軸に平行な二辺を固定一他の二辺を単純支持 とした場合についても計算を行った。このときx方向の変位関数 $u_{i}$ は

$$
u_{i}=\sin \frac{i \pi y}{a}
$$




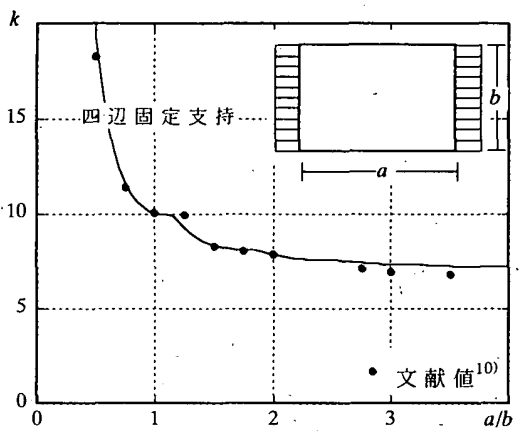

図 4 純圧縮座屈係数

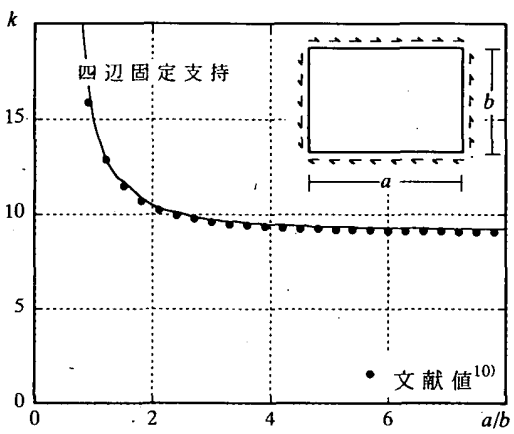

図 5 純せん断座屈係数

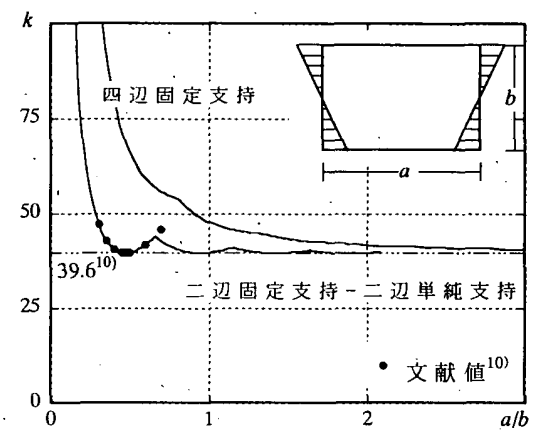

図 6 純曲げ座屈係数
とおいて計算する。能を(58)式のようにおく場合, 二つの正方行列を作 る過程で(40)式, (57)式中の各Uが本研究のものと異なるが, この場合 の各Uについては既往の研究泉を参照するものとする。二辺固定一二 辺単純支持の場合はこれを参照し，座屈係数を求めることとする。こ れらの解析結果を既往の研究結果 ${ }^{10}$ とともに図 6 に示す。なお, 辺長 比が無限大になる場合の二辺固定-二辺単純支持の座屈係数の収束値 についても併せて示す。二辺固定一二辺単純支持の座屈耐力は, 辺長 比が無限大の領域において四辺固定支持の座屈耐力を近似できると考 えられる。

\section{4 変位級数の項数と解の収束性}

図 4〜図 6 より純圧縮, 純せん断, 純曲げ応力状態のいずれの場合 においても,本研究の解析結果と既往の研究の結果とは良い対応を示 していることが分かる。本研究で変位関数として提案する級数は直交 関係は満たしていないものの, $i, j$ をそれぞれ 1〜20までとって計算 すれば,様々な波形の座屈に対して十分な精度によって座屈係数を算 出できている。しかし，これほど多くの級数項を用いなくても座屈係 数を精度良く算出することは十分可能であると考えられる。そこで, 本節では級数項の増加による解の収束性についての確認を行い, 座屈 耐力を算出する上で適切な級数項数について論じる。なお，この検証 には，波形の最も複雑なものとして純せん断の場合を用いている。

まず, $\mathrm{x}$ 方向の变位級数の項数 $i$ の増加による解の収束性について 考える。y方向の変位級数の項数 $j$ を一定にし; $i$ を $1 \sim 20$ まで増加 させた時の座屈係数の収束の様子を図 7 に示す。なお, 解の収束性は 辺長比 $\lambda(=a / b)$ によって变化すると考えられるため, $\lambda=2$ および $\lambda$ =10のそれぞれについて座屈係数の収束性を示している。また，それ

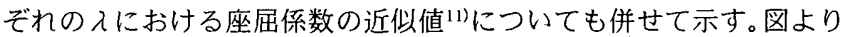

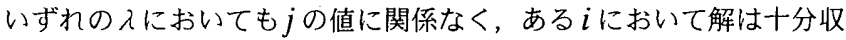
束するようになる。必要な $\mathrm{x}$ 方向の変位級数の項数は, $\mathrm{y}$ 方向の変位 級数の項数に関係なく，入にようてほぼ決定されると考えられる。そ

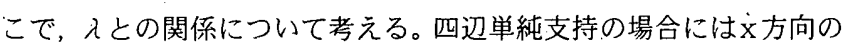
波の数は入とおおむね等しくなることから, 少なくとも $i$ は入程度必 要であると考えられる。しかし，図 7 よりどちらの入においても $i=$ $\lambda$ では十分収束しているとは言えず， $\lambda$ の 1.5 倍から 2.0 倍程度の項 数が必要となることが分かる。これは，固定支持の場合には，単純支 持の場合に比べて, 各辺から拘束を受け座屈波形が複雑になるためで あると考えられる。

つづいて, y 方向の変位級数の項数 $j$ の增加による解の収束性につ いて考える。図 8 に妨向の変位級数の項数 $i$ を一定にし, $j$ を 1 20 まで増加させた時の座屈係数の収束の様子を示す。なお, 前述の結

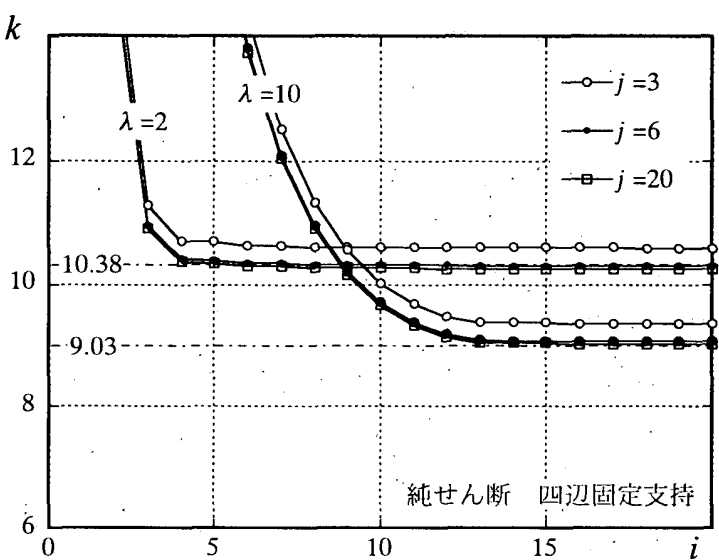

図 7 級数項の増加と解の収束性 $(\mathrm{x}$ 方向)

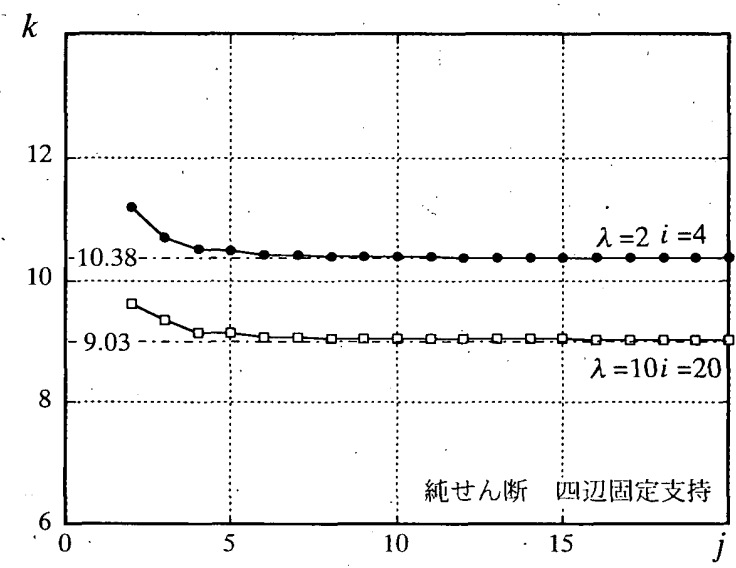

図 8 級数項の增加と解の収束性(y 方向)

果より, $i$ は $\lambda$ の 2 倍としている。図より $i$ を適切にとれば, $j$ を大き な值としなくとも十分な精度で収束することが分かる。 $j=3$ とした場 合でも図中に示した近似解との誤差は， $\lambda=2$ で $3.2 \%, \lambda=10$ で 3.7 \%程度の小さいものである。また，解が十分に収束するy 方向の変位 級数の項数は $\lambda$ の值によらず, ほぼ一定である。これは辺長比が 1 以 上であれば，y方向の座屈波形は辺長比によらず常に 1 波となり， $\lambda$ によってほとんど変化しないためであると考えられる。よって $\lambda \geqq 1$ の範囲においては，jの値は 5 ，あるいは6 程度としておけば十分な精 度で解は得られると言える。

以上より,本研究で提案する变位関数を用いて十分精確な值を得る ためには, $i$ の值は $\lambda$ の 2 倍程度, $j$ の值は 6 程度とする必要があると 言える。ただし，これは辺長比が 1 以上となる場合においてであり， 
1 以下となりy方向に多くの波を生じる場合においては $j$ の値を多く とる必要があると考えられる。しかし，この場合はこれまでの議論の $\mathrm{x}$ とyを入れ替えればよいと考えられるため, 解を十分収束させるた

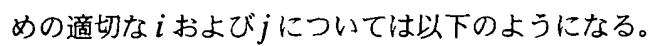

$$
\begin{aligned}
& \lambda \geq 1 \text { のとき } i=2 \lambda \quad j=6 \quad \ldots \ldots \text { (59) } \\
& \lambda \leq 1 \text { のとき } \quad i=6 \quad j=2(1 / \lambda)
\end{aligned}
$$

ただし， $i$ または $j$ が 6 末満となる場合には 6 とする。

以上のように本研究で変位関数として提案する級数は直交関係を満 たしていないものの, 収束性もよく, $i, j$ を適切にとって計算すれば, 様々な波形の座屈に対して十分な精度によって座屈係数を算出でき る。したがって，この変位関数をエネルギー法に適用することによっ て座屈固有値を求める手法は十分妥当であると言える。

\section{§5. 不均等曲げせん断力を受ける四辺固定支持平板の座屈荷 重算出のための一般的解法}

前章において本研究で提案する変位関数の妥当性は示された。本章 では図 9 に示すような不均等曲げせん断力を受けるH形断面梁ウェブ を，四辺固定支持平板と見なし，その座屈荷重を算出する手法につい て述べる。

変位関数および解法原理については 2 章および 3 章の通りである。 したがって，応力状態から行列 $\mathbf{B}^{\prime}$ が定まれば(33)，(40)式によって座 屈係数が算出される。

図 1 および図 9 より $\mathrm{x}$ 方向の直応力度すなわち曲げ応力度的は,

$$
\sigma_{x}=\sigma_{x 1}\left(1-\frac{\beta}{a} x\right)\left(1-\frac{2}{b} y\right) \ldots \ldots \ldots
$$

と表せる。

ここで， $\beta$ は曲げ応力の $\mathrm{x}$ 軸方向の勾配を表しており，

$M_{1}+M_{2}=\beta M_{1} \ldots \ldots \ldots \ldots \ldots$ (62)

$\therefore M_{2}=-(\beta-1) M_{1} \ldots \ldots \ldots \ldots \ldots$ (63)

である。 $\beta=0$ なら純曲げ, $\beta=2$ で逆対称曲げとなる。

また, $\sigma_{x 1}$ は $x=0, y=0$ での曲げ応力度であり, 最大曲げ応力度であ る。したがって，梁左端に作用するモーメント $M_{1}$ を用いて

$$
\sigma_{\mathrm{x} 1}=\frac{M_{1}}{Z}=\frac{2 M_{1}}{b l} \ldots \ldots \ldots \ldots \ldots \text { (64) }
$$

と表せる。ここで $Z$ はH形断面梁の断面係数であり，I は断面二次 モーメントである。なお，本研究においてはこれらの断面定数は， $\mathrm{H}$ 形断面梁のウェブおよびフランジを図 9 に示すようにそれぞれ面積の 集中した線材と考えて算出するものとする。

つづいて，せん断応力度分布について考える。せん断応力度分布は

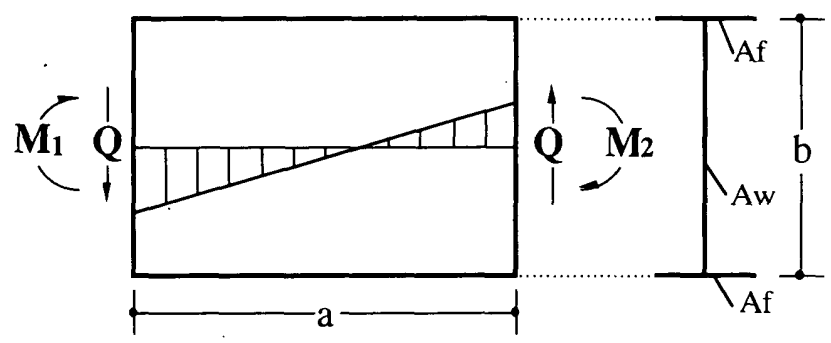

図 9 不等曲げおよびせん断を受けるH形断面梁
梁断面に作用するせん断力 $Q$ によって次の式のように表せる。

$$
\tau_{\mathrm{xy}}=\frac{Q S}{b I}=\frac{Q}{A_{\dot{w}}} \cdot\left\{\frac{I_{f}}{I}+\frac{I_{w}}{I} \cdot \frac{6}{b^{2}} y(b-y)\right\}
$$

ここで, $I_{f}, I_{w}$ はそれぞれ梁のフランジおよびウェブによる断面二次 モーメントであり, $A_{w}$ はウェブの断面積である。ここで $Q / A_{w}$ は梁に作 用する平均せん断応力度であるので $\bar{\tau}$ とおくと，せん断応力度分布は 次のように表せる。

$$
\begin{array}{r}
\tau_{\mathrm{xy}}=\bar{\tau} \cdot\left\{\frac{I_{f}}{I}+\frac{I_{w}}{I} \cdot \frac{6}{b^{2}} y(b-y)\right\} \quad \ldots \ldots \ldots \ldots \text { (66) } \\
\text { ただし }, \quad \bar{\tau}=\frac{Q}{A_{w}} \ldots \ldots \ldots \text { (67) }
\end{array}
$$

このようにして,(61)式拉よび(66)式の形で直応力度分布, せん断応 力度分布がそれぞれ表されるがこれらはそれぞれ独立ではない。 $\sigma_{x 1}$ と $\bar{\tau}$ の間には従属関係があるのは明らかである。その関係について考え る。H形断面梁に作用する曲げモーメントとせん断力の関係より，

$Q=\left(M_{1}+M_{2}\right) / a \ldots \ldots \ldots \ldots$ (68) (63)式より

$Q=\beta M_{1} / a \ldots \ldots \ldots \ldots \ldots$ (69) さらに(64)式, (67)式を代入すると,

$$
\begin{aligned}
& \bar{\tau} A_{w}=\frac{\beta}{a} \cdot \frac{2 I}{b} \cdot \sigma_{\mathrm{x} 1} \ldots \ldots \ldots \ldots \ldots \ldots(70) \\
& \therefore \bar{\tau}=\frac{2 I \beta}{a b A_{w}} \cdot \sigma_{\mathrm{x} 1}=\frac{\beta}{\lambda} \cdot \frac{2 I}{b^{2} A_{w}} \cdot \sigma_{\mathrm{x} 1} \ldots \ldots \ldots \ldots \text { (71) } \\
& \text { ここで } \lambda \text { はウェブの辺長比である。 }
\end{aligned}
$$

(71)式は曲げ応力勾配を表す $\beta$, 辺長比 $\lambda$ と $2 I / b^{2} A_{w}$ によって, 平均 せ九断応力度 $\bar{\tau}$ と最大曲げ応力度 $\sigma_{\mathrm{x} 1}$ との関係を表すものである。こ こで $2 I / b^{2} A_{w}$ は断面によって定まる值であり，取り扱うH形断面に よって変化する。そこでこの值をせん断曲げ比 $\eta$ とおくう。なわち,

$$
\begin{aligned}
& \eta=\frac{2 I}{b^{2} A_{w}} \ldots \ldots \ldots \ldots \ldots \ldots \ldots \ldots \ldots \\
& \therefore \bar{\tau}=\frac{\eta \beta}{\lambda} \cdot \sigma_{1} \ldots \ldots \ldots \ldots \ldots \ldots(74)
\end{aligned}
$$$$
\text { ここで, } I \text { を } A_{f}, A_{w} \text { によって表すと }
$$

$$
I=I_{f}+I_{w}=\frac{b^{2} A_{f}}{2}+\frac{b^{2} A_{w}}{12}
$$

よって,(73)式より

$$
\therefore \eta=\frac{A_{f}}{A_{w}}+\frac{1}{6}
$$

となりせん断曲げ比 $\eta$ はフランジとウェブの断面積比によって表せる ことが分かる。また, (73)式中の $A_{w}$ を $I_{w}$ で表すと

$$
\eta=\frac{2 I}{b^{2} A_{w}}=\frac{1}{6} \cdot \frac{I}{I_{w}}
$$

であるので, (66)式中の $I w / I, I f / I$ は以下のように表すことができる。

$$
\frac{I_{w}}{I}=\frac{1}{6 \eta} \quad \frac{I_{f}}{I}=1-\frac{I_{w}}{I}=1-\frac{1}{6 \eta}
$$

したがって(61), (66), (74), (78)式より, 直応力度分布とせん断応力 度分布は梁せい $b$, せん断曲げ比 $\eta$, 辺長比 $\lambda$, 曲げ勾配定数 $\beta$, 最 大曲げ応力度 $\sigma_{x_{1}}$ により以下のように表せる。

$$
\sigma_{\mathrm{x}}=\sigma_{\mathrm{x}_{1}}\left(1-\frac{\beta}{b \lambda} x\right)\left(1-\frac{2}{b} y\right)
$$


$\tau_{x y}=\sigma_{x 1} \frac{\eta \beta}{\lambda}\left\{\left(1-\frac{1}{6 \eta}\right)+\frac{1}{6 \eta} \cdot \frac{6}{b^{2}} y(b-y)\right\} \ldots \ldots \ldots$ (80)

(79)，(80)式によって応力分布が定められたので，つづいて行列 $\mathbf{B}^{\prime}$ の各成分 $B_{i j m n}^{\prime}$ について考える。(16)式および(79)，(80).式より

$$
\begin{aligned}
& f(x, y)=\left\{1-\frac{\beta}{b \lambda} x\right)\left(1-\frac{2}{b} y\right) \ldots \ldots \ldots \ldots(81) \\
& \alpha g(x, y)=\frac{\beta}{\lambda}\left\{\left(\eta-\frac{1}{6}\right)+\frac{1}{b^{2}} y(b-y)\right\} \ldots \ldots \ldots \ldots(82)
\end{aligned}
$$

となる。したがって $B_{i j m n}^{\prime}$ は次のように表せる。

$$
\begin{aligned}
B_{i j m n}^{\prime}=\int_{0}^{a} \int_{0}^{b}\left\{\left(1-\frac{\beta}{b \lambda} x\right)\left(1-\frac{2}{b} y\right)\left(\dot{u}_{i} v_{j} \dot{u}_{m} v_{n}\right)\right. \\
\left.+\frac{\beta}{\lambda}\left\{\left(n-\frac{1}{6}\right)+\frac{1}{b^{2}} y(b-y)\right\}\left(\dot{u}_{m} v_{n} u_{i} \dot{v}_{j}+\dot{u}_{i} v_{j} u_{m} \dot{v}_{n}\right)\right\} d x d y \ldots \text { (83) }
\end{aligned}
$$

ここで,(83)式の直応力度による項を $S_{1}$, せん断応力度による項を S2 とおき,さらに,

$$
\begin{array}{ll}
U_{7}(i, m)=\int_{0}^{a} x \cdot \dot{u}_{i} \cdot \dot{u}_{m} d x & V_{7}(j, n)=\int_{0}^{b} y \cdot \dot{v}_{j} \cdot \dot{v}_{n} d y \\
U_{8}(i, m)=\int_{0}^{a} x \cdot \dot{u}_{i} \cdot u_{m} d x & V_{8}(j, n)=\int_{0}^{b} y \cdot \dot{v}_{j} \cdot v_{n} d y \quad \ldots \ldots \\
U_{9}(i, m)=\int_{0}^{a} x^{2} \cdot \dot{u}_{i} \cdot u_{m} d x & V_{9}(j, n)=\int_{0}^{b} y^{2} \cdot \dot{v}_{j} \cdot v_{n} d y
\end{array}
$$

とおくと，S1,S2 はそれぞれ以下のように書き換えられる。

$$
\begin{aligned}
& S_{1}=\left\{U_{2}(i, m)-\frac{\beta}{b \lambda} U_{7}(i, m)\right\}\left\{V_{1}(j, n)-\frac{2}{b} V_{6}(j, n)\right\} \quad \cdots \cdots \cdots \\
& S_{2}=\frac{\beta}{\lambda}\left[U_{5}(m, i)\left\{\left(\eta-\frac{1}{6}\right) V_{5}(j, n)+\frac{1}{b} V_{8}(j, n)-\frac{1}{b^{2}} V_{9}(j, n)\right\}\right. \\
& \left.+U_{5}(i, m)\left\{\left(\eta-\frac{1}{6}\right) V_{5}(n, j)+\frac{1}{b} V_{8}(n, j)-\frac{1}{b^{2}} V_{9}(n, j)\right\}\right] \cdots(86)
\end{aligned}
$$

また, (53)式より $S_{2}$ は更に次のように書き換えられる。

$$
\begin{aligned}
S_{2}=\frac{\beta}{\lambda} \cdot U_{5}(m, i) & {\left[2\left(\eta-\frac{1}{6}\right) V_{5}(j, n)+\frac{1}{b}\left\{V_{8}(j, n)\right.\right.} \\
& \left.-V_{8}(n, j)\right\} \\
& \left.-\frac{1}{b^{2}}\left\{V_{9}(j, n)-V_{9}(n, j)\right\}\right] \cdots
\end{aligned}
$$

したがって,(85)，(87)式を用い，appendixを参照することによって 行列 $\mathbf{B}^{\prime}$ が定められる。この行列と(40)式によって定められる行列 $\mathbf{A}^{\prime}$ を(33)式の固有値問題に代入し, 固有値を求めることで, 不均等曲げ せん断力を受ける四辺固定支持平板の座屈係数が求められ，その時の 固有ベクトルから座屈波形が求められる。

また，appendixに示した関数 $\Phi$ 用いると(85), (87)式から $A_{i j, n n}^{i}$ ， Bijnn はそれぞれ次のようになる。

$$
\begin{aligned}
& A_{i j m n}^{\prime}=\frac{1}{\lambda^{2} \pi^{2}}\left\{\Phi_{3}(i, m) \cdot \Phi_{1}(j, n)+\Phi_{1}(i, m) \cdot \Phi_{3}(j, n)+2 \Phi_{4}(i, m) \cdot \Phi_{4}(n, j)\right\} \quad \cdot(88) \\
& B_{i j m n}^{\prime}=\frac{1}{\lambda}\left\{\Phi_{2}(i, m)-\beta \Phi_{7}(i ; m)\right\}\left\{\Phi_{1}(j, n)-2 \Phi_{6}(j, n)\right\} \\
& \quad+\frac{\beta}{\lambda} \cdot \Phi_{5}(m, i)\left[2\left(\eta \cdot \frac{1}{6}\right) \Phi_{5}(j, n)+\left\{\Phi_{8}(j, n)-\Phi_{8}(n, j)\right\}-\left\{\Phi_{9}(j, n)-\Phi_{9}(n, j)\right\}\right](89)
\end{aligned}
$$

各 $\Phi(p, q)$ は $p q$ みの関数であることから, 行列 $\mathbf{A}^{\prime}$, および $\mathbf{B}^{\prime}$ は板の辺長比 $\lambda$, せん断曲げ比 $\eta$, 曲げ勾配定数 $\beta$ からなる行列と なる。したがって,(33)式によって求まる座屈係数 $k$ の值はこれら $\lambda$,

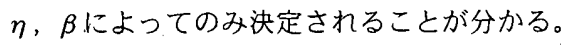

一例として, 図 10 に本解析手法で求めた板のせん断座屈係数曲線 を $\beta=2.0, \beta=1.0$ のそれぞれについて示す。せん断座屈係数は平均せん 断応力度に対する座屈係数である。せん断曲げ比 $う$ は 1.0 および 2.0 としている。この值は現実のH形断面部材におけるせん断曲げ比の範 囲0.5〜2.58に収まるように選んだ。なお, 文献 8 ）において求めら れた，四辺単純支持の場合のせん断座屈係数についても併せて示す。

純せん断応力を受ける場合に比べて曲げ応力度やせん断応力度分布

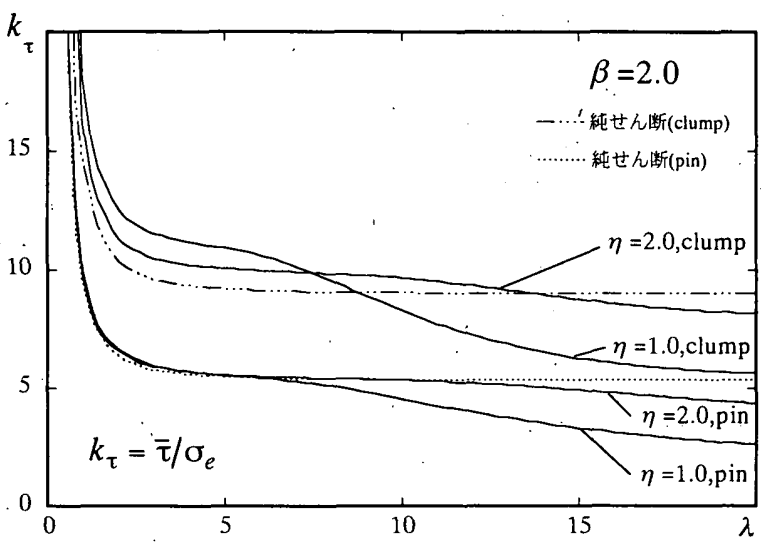

(a) $\beta=2.0$

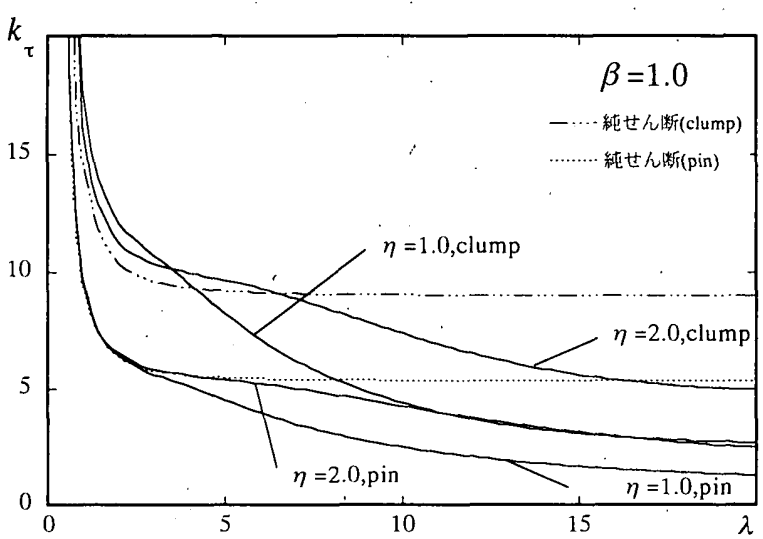

(b) $\beta=1.0$

図 10 不均等曲げせん断力を受ける四辺固定支持平板の座屈曲線

が変化することにより座届曲線にかなりの違いが現れることが分か る。その傾向を見ると, $\lambda$ が小さくせん断力の影響の大きな領域にお いては純せん断の座屈曲線に沿い, $\lambda$ が大きく曲げの影響が強くなる 領域においては純せん断の座屈曲線を大きく下回ることが分かる。こ れは，文献8）における不均等曲げせん断力を受ける四辺単純支持平 板の座屈曲線と同じような傾向である。不均等曲げせん断力を受ける 四辺固定支持平板の弹性座屈性状に関する詳細な考察は別報にて報告 予定である。

\section{\$6. 結}

本研究はこれまで十分な研究がなされてきていない不均等曲げせん 断力を受ける四辺固定支持平板の弾性座屈応力およびその座屈波形を 算出する一般的手法を示した。

本研究では四辺固定支持平板の変位関数を無限級数の形で提案し, それをエネルギー法に適用することにようて複合応力を受ける四边固 定支持平板の座屈応力を求める手法の導出を行った。また，既往の研 究結果が存在する比較的単純な外力条件による手法についても同様に 述べ, その解析結果を既往の研究成果と比較することによって本研究 で提案する変位関数の収束性, 妥当性を示した。

本研究の手法を用いることによって, 不均等曲げせん断力を受ける 四辺固定支持平板の座屈応力度は, 板のアスペクト比, 曲げ応力公 配，せん断曲げ比を定めることによって，多くの級数項をとらず比較 的容易に求めることができる。また, 本研究で提案しだ変位関数は四 
辺固定支持平板の一般的な変位関数であり様々な波形に対応できる。 このため,この変位関数をエネルギー法に適用することによって,こ れまでなされてこなかった様々な複合応力を受ける四辺固定支持平板 の座屈応力を求めることも可能になると考えられる。

\section{参考文献}

1)鈴木敏郎，小野徹郎：筀性設計梁に関する実験的研究(1 3)，日本建築学会論文報 告集, 第168号, pp.77 84, 1970.2, 第171号; Pp.31 36, 1970.5, 第175号, pp.69 74, 1970.9

2)加藤 勉, 秋山 宏, 带. 洋一: 局部座屈を佯うH形梁部材の梁形, 日本建築学会 論文報告集，第257 号, pp.49 58, 1977.7

3)加藤 勉, 中尾雅躬: 局部座屈に支配されるH形断面部材の耐力と変形能力, 日本 建築学会檴造系論文集，第 458 号, pp.127 136, 1994.4

4)與田香二, 今井克彦, 黑羽啓明, 小川厚治: 幅厚比の大きいH形断面曲げ材の変形 举動予洌に関する研究，日本建築学会構造系論文報告集, 第411号, pp.83 96, 1990.5 5)鉿水敏郎，小野微郎，金箱温春 : せん断曲げを受ける鉄骨H非断而梁の局部座屈举 動と唯性変形能力，日本建築学会論文報告集，第 260 号，pp.91 98，1977.10

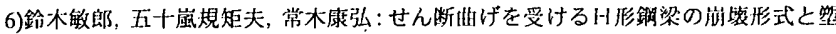
性変形能力に関する䂺究，日本建築学会梅浩系論文集，第547㝵，pp.185 191， 2001.9

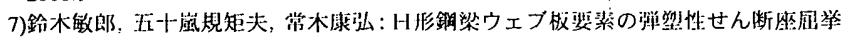

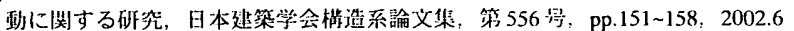

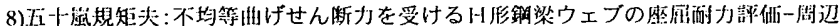

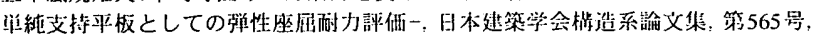
pp.135 141, 2003.3

9)Timoshenko \&Gere : Theory of Elastic Stability, 1963

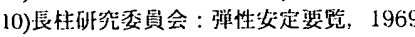

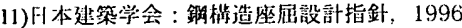

-appendix-

㚆位風数 $u_{i}$ およびv $v_{j}$ を以下ようにおくとき。

$$
u_{i}=\sin \frac{\pi x}{a} \sin \frac{i \pi x}{a} \quad v_{j}=\sin \frac{\pi y}{b} \sin \frac{j \pi y}{b}
$$

各䖽分䦥数を以下に示す。

$$
\begin{aligned}
& U_{1}(i, m)=a \Phi_{1}(i, m) \quad V_{1}(j, n)=b \Phi_{1}(j, n) \\
& U_{2}(i, m)=\frac{1}{a} \Phi_{2}(i, m) \quad V_{2}(j, n)=\frac{1}{b} \Phi_{2}(j, n) \\
& U_{3}(i, m)=\frac{1}{a^{3}} \Phi_{3}(i, m) \quad V_{3}(j, n)=\frac{1}{b^{3}} \Phi_{3}(j, n) \\
& U_{4}(i, m)=\frac{1}{a} \Phi_{4}(i, m) \quad V_{4}(j, n)=\frac{1}{b} \Phi_{4}(j, n) \\
& U_{s}(i, m)=\Phi_{s}(i, m) \quad V_{s}(j, n)=\Phi_{s}(j, n) \\
& U_{6}(i, m)=a^{2} \Phi_{6}(i, m) \quad V_{6}(j, n)=b^{2} \Phi_{6}(j, n) \\
& U_{7}(i, m)=\Phi_{7}(i, m) \quad V_{7}(j, n)=\Phi_{7}(j, n) \\
& U_{8}(i, m)=a \Phi_{8}(i, m) \quad V_{8}(j, n)=b \Phi_{8}(j, n) \\
& U_{9}(i, m)=a^{2} \Phi_{9}(i, m) \quad V_{9}(j, n)=b^{2} \Phi_{9}(j, n) \\
& \Phi_{1}(p, q)=\left\{\begin{array}{lr}
\frac{3}{8} & (p=q=1) \\
\frac{1}{4} & (p=q \neq 1) \\
-\frac{1}{8} & (p-q= \pm 2) \\
0 & (\text { else })
\end{array}\right.
\end{aligned}
$$

$\Phi_{2}(p, q)=\left\{\begin{array}{lr}\frac{\pi^{2}}{4}\left(p^{2}+1\right) & (p=q) \\ \frac{\pi^{2}}{32}(p+q)^{2} & (p-q- \pm 2) \\ 0 & (e l s e)\end{array}\right.$
$\Phi_{3}(p, q)=\left\{\begin{array}{cr}\frac{\pi^{4}}{4}\left(p^{4}+6 p^{2}+1\right) & (p=q) \\ -\frac{\pi^{4}}{32}(p+q)^{4} & (p-q= \pm 2) \\ 0 & (e l s e)\end{array}\right.$

$\Phi_{4}(p, q)=-\Phi_{2}(p, q)$

$\Phi_{5}(p, q)=\left\{\begin{array}{cc}\frac{1}{4}\left\{\frac{2 p}{p+q}-\frac{p+1}{p+q+2}-\frac{p-1}{p+q-2}-\frac{2 p}{p-q}+\frac{p+1}{p-q+2}+\frac{p-1}{p-q-2}\right\} & (p+q: \text { odd }) \\ 0 & (p+q: \text { even })\end{array}\right.$

$\Phi_{6}(p, q)=\left\{\begin{array}{lr}\frac{3}{16} & (p=q=1) \\ \frac{1}{8} & (p=q \neq 1) \\ -\frac{1}{16} & (p-q= \pm 2) \\ 0 & (p \neq q, p-q \neq \pm 2, p+q: \text { even }) \\ \frac{1}{4 \pi^{2}}\left\{\frac{2}{(p+q)^{2}}-\frac{1}{(p+q+2)^{2}}-\frac{1}{(p+q-2)^{2}}-\frac{2}{(p-q)^{2}}+\frac{1}{(p-q+2)^{2}}+\frac{1}{(p-q-2)^{2}}\right\} & (\text { else })\end{array}\right.$

$\Phi_{7}(p, q)=\left\{\begin{array}{lr}\frac{\pi^{2}}{8}\left(p^{2}+1\right) & (p=q) \\ -\frac{\pi^{2}}{64}(p+q)^{2} & (p-q= \pm 2) \\ 0 & (p \neq q, p-q \neq \pm 2, p+q: \text { even }) \\ \frac{1}{4 \pi^{2}}\left\{\frac{2(p q-1)}{(p+q)^{2}}-\frac{(p+1)(q+1)}{(p+q+2)^{2}}-\frac{(p-1)(q-1)}{(p+q-2)^{2}}-\frac{2(p q+1)}{(p-q)^{2}}+\frac{(p+1)(q-1)}{(p-q+2)^{2}}+\frac{(p-1)(q+1)}{(p-q-2)^{2}}\right\} & (\text { else })\end{array}\right.$

$\Phi_{8}(p, q)=\left\{\begin{array}{lr}-\frac{3}{16} & (p=q=1) \\ -\frac{1}{8} & (p=q \times 1) \\ -\frac{1}{64}\left\{\frac{16}{p+q}-\frac{4(p+q)}{p q}-3(p+q)-4\right\} & (p-q= \pm 2) \\ \frac{1}{8}\left\{\frac{2 p}{p+q}-\frac{p+1}{p+q+2}-\frac{p-1}{p+q-2}-\frac{2 p}{p-q}+\frac{p+1}{p-q+2}+\frac{p-1}{p-q-2}\right\} & (p \neq q, p-q * \pm 2, p+q: \text { odd }) \\ -\frac{1}{8}\left\{\frac{2 p}{p+q}-\frac{p+1}{p+q+2}-\frac{p-1}{p+q-2}-\frac{2 p}{p-q}+\frac{p+1}{p-q+2}+\frac{p-1}{p-q-2}\right\} & \text { (else) }\end{array}\right.$

$\Phi_{9}(p, q)=\left\{\begin{array}{lr}-\frac{3}{16} & (p=q=1) \\ -\frac{1}{8} & (p=q \neq 1) \\ -\frac{1}{64}\left\{\frac{16}{p+q}-\frac{4(p+q)}{p q}-3(p+q)-4\right\} & (p-q= \pm 2) \\ -\frac{1}{8}\left\{\frac{2 p}{p+q}-\frac{p+1}{p+q+2}-\frac{p-1}{p+q-2}-\frac{2 p}{p-q}+\frac{p+1}{p-q+2}+\frac{p-1}{p-q-2}\right\} & (p \neq q, p-q \neq \pm 2, p+q: \text { even }) \\ \frac{1}{8}\left\{\frac{2 p}{p+q}-\frac{p+1}{p+q+2}-\frac{p-1}{p+q-2}-\frac{2 p}{p-q}+\frac{p+1}{p-q+2}+\frac{p-1}{p-q-2}\right\} & \\ -\frac{1}{2 \pi^{2}}\left\{\frac{2 p}{(p+q)^{3}}-\frac{p+1}{(p+q+2)^{3}}-\frac{p-1}{(p+q-2)^{3}}-\frac{2 p}{(p-q)^{3}}+\frac{p+1}{(p-q+2)^{3}}+\frac{p-1}{(p-q-2)^{3}}\right\} & \text { (else) }\end{array}\right.$

（2003年 1 月 10 日原稿受理，2003年 6 月 9 日採用決定） 